\title{
Communication
}

\section{Asymmetric Total Synthesis of Herbarumin III: Introduction of the syn-1,3-Diol Moiety from an Optically Pure Hydroxy Epoxide Resolved by HKR}

\author{
Jieun Lee, Young-Hee Jung, and Jinsung Tae ${ }^{\star}$ \\ Department of Chemistrv and Center for Bioactive Lolecular Hybrids (CBM/H). Yonsei Universit, Seoul 120-749, Korea \\ "E-mail: jstaeótronsei.ac.kr \\ Received February 5. 2007
}

Key Words : Epoxide. Herbarumin III, Macrolactone. Ring-closing metathesis, Total synthesis

Herbarumin III (1) isolated from the fermentation broth and nucelium of the fungus Phoma herbanm displays significant phytotoxic effects against seedlings of $A$. hypochondriacus. ${ }^{3}$ The herbarumin macrolides (1-3, Figure 1) interact with bovin-brain calmodulin and inhibit the activation of the calmodulin-dependent enzyme cAMP phosphodiesterase. Construction of the 10 -membered lactone ring and the streocontrol of syn-1.3-diol unit are two major issues in the total sy'nthesis of herbarumin III (1). In the previous total synthesis of $1{ }^{2}$ the 10 -membered lactone ring was synthe-

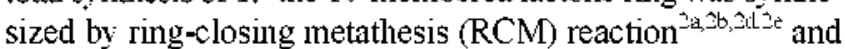
Yamagnchi's lactonization method. ${ }^{3 \mathrm{C}}$ Asymmetric synthesis of the $5 y$-1.3-diol moiety have been achieved using chiral pool methods ${ }^{\text {a.. } t \text {.?d }}$ chemoenzymatic method. ${ }^{\text {tc }}$ and asymmetric allylation/Sharpless epoxidation method ${ }^{\hat{\jmath}}$ Herein. we would like to report an asymmetric total synthesis of herbarumin III (1) starting from an enantiomerically pure

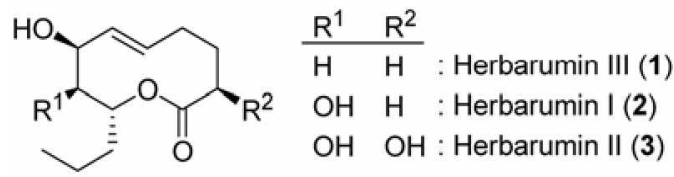

Figure 1

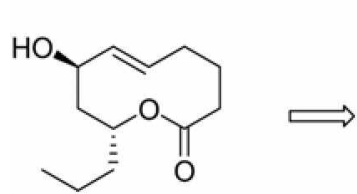<smiles>C=CCCCC(=O)O[C@H](CCC)CC(P)C=C</smiles>

Herbarumin III (1) 4<smiles>C=CCCCC(=O)O</smiles><smiles>[Z7]C(CCC)C([SeH])CC1CO1</smiles><smiles>C=C[C@H](C[C@@H](O)CCC)P(=O)(O)CCC</smiles>

Scheme 1. Retrosynthetic analy sis for herbarumin III (1)

hydroxy epoxide generated by using Jacobsen's hydrolytic kinetic resolution (HKR) method to install the syn-1.3-diol moiety:

Retrosynthetically (Scheme 1), the macrolactone ring of 1 could be constructed by RCM reaction ${ }^{3}$ at the final stage and the corresponding diene 4 would be prepared from alcohol 6 and 5-hexenoic acid (5). The sin-1.3-diol moiety of 6 could be introduced by using a nucleophilic epoxide opening reaction of epoxide 7 .

The starting epoxide 7 is prepared from (-)-8 that we have prepared previously ${ }^{4}$ by using Jacobsen's hydrolytic kinetic resolution (HKR) method. ${ }^{5}$ Removal of double bond in 8 by catalytic hydrogenation followed by treatment with dimethylsulfonium methylide ${ }^{6}$ yields the sw-1,3-diol moiety 9 in good yield (Scheme 2). Protection of the allylic alcohol using ethyl vinyl ether (EVE) in the presence of PPTS (pyridinium para-toulenesulfonate) in dichloromethane gives 10

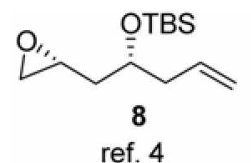

OEt<smiles>C=CC(C[C@@H](O[GaH])OC(C)OCC)OCCC</smiles>

10

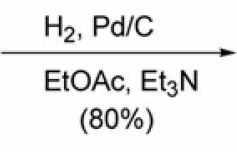

$n$-BuLi, THF (90\%)
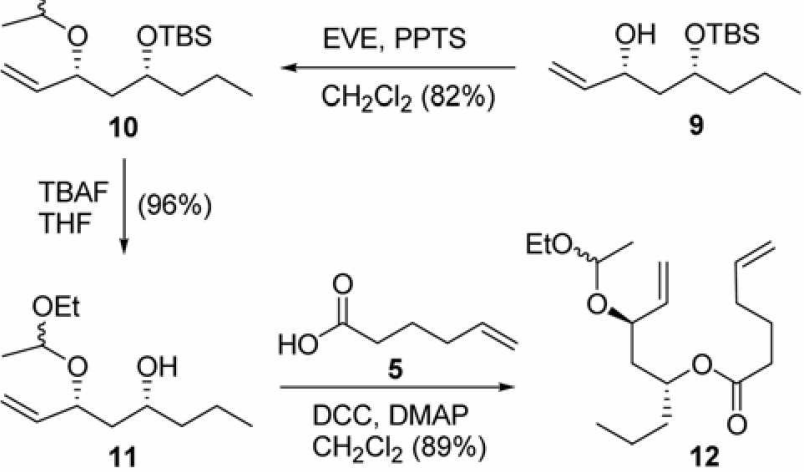

Scheme 2. Asymmetric synthesis of RCM precursor 12 


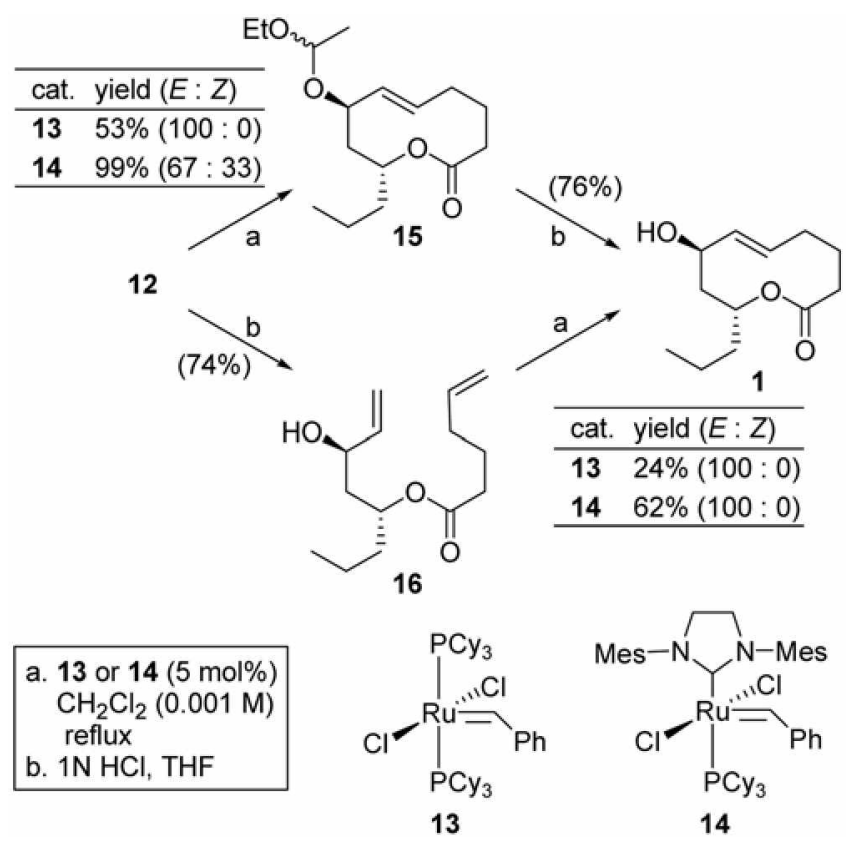

Scheme 3. Completion of total synthesis of herbarumin III (1).

in $82 \%$ yield. Subsequent deprotection of the TBDMS (tertbutyldimethylsilyl) ether in $\mathbf{1 0}$ using TBAF (tetrabutylammonium fluoride) in THF affords alcohol 11 which is then coupled with 5-hexenoic acid (5) using DCC and DMAP in dichloromethane to give the RCM precursor 12 in good yield ( $89 \%$ ).

With the diene 12 in hand. we next investigated ringclosing metathesis mediated macrolactonization reaction ${ }^{7}$ as shown in Scheme 3. Treatment of compound 12 with $5 \mathrm{~mol}$ $\%$ Grubbs' cataly'st 13 under high dilution conditions $(0.001$ $\mathrm{M}$ in $\left.\mathrm{CH}_{2} \mathrm{Cl}_{2}\right)$ produces 15 in $53 \%(E / Z=100: 0)$. ${ }^{8}$ Under the same conditions. the second generation Grubbs' catalyst 14 yields $15 \mathrm{in} 99 \%$ yield as an alkene mixture $(E / Z=67: 33)$. On the other hand. the cyclization reactions of alcohol 16 with either 13 or 14 produce only herbarumin III (1) in $24 \%$ and $62 \%$ respectively. Overall. the 2 nd generation Grubbs" catalyst 14 is better for the cyclization reactions ( $99 \%$ for 12 and $62 \%$ for 16 ). Spectral data for 1 are consistent with those reported in the literature.

In conclusion. an asynmetric total synthesis of herbarumin III has been accomplished by employing a 7-step sequence starting from an enantiomerically pure hydroxy epoxide generated by using Jacobsen's hỵdrolytic kinetic resolution (HKR) method. The macrolactone ring was constructed by employing a RCM reaction and the syn-1,3-diol moiety was introduced by using a nucleophilic epoxide opening reaction.

Acknowledgement. This work was supported by the Center for Bioactive Molecular Hybrids (MOST/KOSEF) and Korea Research Foundation Grant (KRF-2003-015C00360). Y.-H. J. and J. L. acknowledge the fellowship of the $\mathrm{BK} 21$ program from the Ministry of Education and Human Resources Developinent.

\section{References}

1. Rivero-Cruz, J. F.: Macias, M.; Cerda-Garcia, C. M.: Mata. R. d. Yat. Prod. 2003, 66, 511

2. (a) Gurjar. M. K.: Kamakar. S.: Mohapatra. D. K. Tetrahedron Lett. 2004. 45,4525 , (b) Gurjar, M. K.: Nagaprasad, R.; Ramanna. C. V: Karmakar. S.: Mohapatra. D. K. ARKLUC 2005. 237. (c) Nanda. S. Tetrahedron Lett. 2005. +6. 3661. (d) Salaskar. A.: Sharma. A.: Chattopadhyay. S. Temohedon: Anmmen 2006.17. 325. (e) Boruwa. J.: Gogoi, N.; Barua, N. C. Org. Biomol. Chem. 2006. 4, 3521

3. For reviews on olefin metathesis, see: (a) Grubbs, R. H: Chang. S. Tetrahedron 1998. 5t.4413, (b) Furstner. A. Angew Chem, Int. Ed. 2000. 39. 3012. (c) Diver. S. I.: Giessert. A. T. Chem. Rev: 2004. 10f. 1317. (d) Poulsen. C. S.: Madsen. R. Symhesis 2003. I. (e) Mori. M. Top. Organomet. Chem. 1998, 1.133.

4. Kim. Y.J:- Tae. J. Symlett 2006,61.

5. (a) Tokunaga. M: Larrow. J. F.: Kakiuchi, F: Jacobsen. E. N. Science 1997. 277. 936. (b) Brandes. B. D.: Jacobset1. E. N. Tetrahedron: As7mmetry 1997. 8. 3927.

6. Alcaraz. L: : Harnett. J. T.: Mioshowshi. C.: Martel. J. P.: Le Gall. T.: Shin, D.-S.: Falck. J. R. Tetrahedron Lett. 1994. 35.5419.

7. Gradillas, A : Perez-Castells, J. Angew. Chem. Wh. Ed 2006. 45. 6068 .

8. The $(E Z)$ ratios were determined atter conversion to herbarumin (1). The coupling constants between the vinyl protons are $J-16.0$ $\mathrm{Hz}$ for $15 . J=16.0 \mathrm{~Hz}$ for 1 and $J=11.3 \mathrm{~Hz}$ for $(Z)$-isomer of 1 .

9. The RCM dimerization product is not observed for this ethoxy ethyl protected alcohol substrate $\mathbf{1 5}$. 